\title{
Report on the 8th National Scientific Conference in the "Education Yesterday, Today and Tomorrow" series. Adam Mickiewicz University in Poznań, 24 May 2018
}

DOI: $10.14746 /$ bhw.2018.38.18

On 24 May 2018, under the patronage of the Dean of the Faculty of Educational Studies, Prof. Dr Agnieszka Cybal-Michalska, the Eighth National Scientific Conference in the "Education Yesterday, Today and Tomorrow" series, organised by the Student History of Culture and Education Academic Club in cooperation with the Department of History of Education, was held. This year's theme of the conference focused on the character of the student: "The students: who were they, who are they, who can they be?"

The Scientific Committee of the conference was composed of Prof. Wiesław Jamrożek, PhD, Prof. Marek Budajczak, PhD, Prof. Krzysztof Ratajczak and Michał Nowicki, PhD.

The conference was officially opened by the Deputy Dean of the Faculty of Educational Studies, Prof. Waldemar Segiet, PhD. The Deputy Dean welcomed all students and invited guests and emphasised that this is the eighth conference of the series at the Faculty of Educational Studies, which has a positive reputation in the community and fits perfectly into the academic activities of the Faculty of Educational Studies.

The session was opened with a speech by Prof. Marek Budajczak, PhD, who presented a paper entitled "Studens sola aut solus". In his paper, the professor stressed that despite the pressure of other people and the world, education to a large extent seems to be a "private" matter for every student. M. Budajczak also spoke about the fact that the relations between the agens and patiens of education are manifold and worth reflecting on.

The second speaker in this part of the conference was Krzysztof Ratajczak, PhD, who presented the topic "What caused student trauma in a medieval school?" Dr Ratajczak spoke about what caused fear among the students of centuries ago, what were the relations between teacher and student, family home and school, what was the intellectual atmosphere in school, language learning and criminal issues. This allowed us to compare how a student can study today and how things used to be.

The last speaker in the first block of the conference was Juliusz Iwanicki, PhD, who presented his paper "On Platonic-Augustinian epistemology for visual cognition - a pupil in the old and contemporary world of ideas". In his paper, Dr Iwanicki raised the question whether in the present times, when memes have become so popular among young people, there is still room for the classical philosophy of upbringing? The doctor used memes as an additional source of philosophical knowledge in his own classes; however, he does not give up on classical methods, which results in student interest. Thus, we can conclude that in the area of picture culture there are abutments that can support the student's development. The lectures were followed by a lively discussion.

The second session of the conference began with a paper by Agata Strzelczyk, whose topic was "Relations between a student and a teacher on the example of Grand Duke Alexander Pavlovich Romanov and Frédéric-César de La Harpe". Ms Strzelczyk present- 
ed us with the education and upbringing of the first grandson of Empress Catherine II, and the future tsar Alexander I. Catherine II personally chose his teachers, and for his tutor, she chose Frédéric-César de La Harpe, who was a mentor and one of the people who had the greatest influence on Alexander. De La Harpe accompanied Alexander until he reached the age of majority, and when Alexander ascended the throne, he became one of his advisers.

The next paper, entitled "Who is the student in the pedagogical theory of Janusz Korczak?" was presented by Izabela Napierała. The aim of the paper was to present Janusz Korczak's views on the student as a human being. Ms Napierała spoke about how a child should be treated, according to Janusz Korczak, and how to solve their problems. The speaker drew attention to the aspect of the student's existence as a human being, how they look and what concerns and reasons for joy they have.

Sarah Taylor was the last speaker in this block, speaking about "The scout as a student". Sarah Taylor based her paper on her eight years of experience working with children in the international scouting organisation Royal Rangers. Guests gathered at the conference were shown the essence of teaching through practice and entrusting responsibility, functions and positions to which children do not have access on a daily basis.

After the coffee break, which began just after the discussion about the papers in block two, the third block of papers began.

The first to present was Aleksandra Bawolska with the paper "Student with selective mutism - the challenge of contemporary pedagogy?" The speaker explained to those present that selective mutism is a childhood disorder, the main symptom of which is the lack of speech in some social situations. During her speech, the speaker presented possible methods of diagnosing mutism in a child and how the child can be helped.

Beata Iwanicka was the second speaker with the paper "Education of students with hearing impairments - educational challenges". The paper was very moving because Ms Iwanicka presented us with the problems people with hearing loss have to face on a daily basis. We learned how few institutions in Poland are adapted for such people and what professions are intended for them. Ms Iwanicka presented the historical issues of the development of education of students with hearing impairments, while at the same time addressing the current challenges involving this type of students in education.

Monika Łozińska was the last speaker in this part of the conference, and presented the topic "Pupils of all schools, unite in cheating! The phenomenon of student dishonesty in the light of research". Ms Łozińska, on the basis of her research, showed that the phenomenon of school dishonesty (commonly referred to as cheating) among students of primary, middle and secondary schools is practically a given. In fact, students consider this to be a normal phenomenon, part of the school's tradition and a form of rebellion against school requirements.

After the discussion on the subjects of the third block, the fourth block took place. Anna Ślebioda was the first speaker to present her paper "Shaping the heart as the most important element of the education of disabled girls in the light of Edith Stein's theory". According to Edith Stein, the main core of a woman should be shaping the heart. This is because it is the heart that constitutes the centre of the female soul. According to Stein's 
theory, only its proper formation allows a woman to develop fully. This formation starts as early as the school age. The presentation by Ms Ślebioda confronted the Edith Stein's with the available forms of education for disabled girls.

Next, Aleksandra Sulczewska gave a presentation titled "Between the individualisation of teaching and shaping a sense of community. Difficulties in defining the role of the pupil in pre-school education". Ms Sulczewska reflected in her lecture on whether a child in a kindergarten is a pupil or perhaps already a student, as well as how a pre-schooler should be treated in order to reconcile following their individual needs with shaping a sense of community? What role can a kindergarten group play - can it be a "small homeland" with its own rights, governments and even strikes? It was precisely these questions that the speaker tried to answer during her speech.

The last speaker in this block was Dobrawa Gumbis, a student of the Faculty of Educational Studies, who dealt with the subject of "Sensual Experience and Sensory Learning and Child Development". Mr Gumbis based her paper on her own experience gained in the "Czar podkowy" educational homestead operated by her parents. Thanks to the speech, we learned about a place where learning is not boring and limited at all. In the educational homestead, children can absorb the world with all their senses, with their entire bodies. It is the experience that makes learning easier and more enjoyable, and most importantly, the knowledge gained in this way stays with us for longer. Ms Gumbis' speech was followed by a discussion on the papers from block four.

After the lunch break, the penultimate block began, in which Mariusz Przybyła, PhD, was the first to deliver his paper "Herbert and Skinner today - how do students learn?" Dr Przybyła's speech was supposed to give us an opportunity to think about whether we are innovative today or whether we are repeating the previously developed models given to us by Herbert and Skinner? Progressive as he was at the time, Herbert seems to be anachronistic today, unfit for the digital reality and increasingly "guilty" of the present school inactivity. Dr Przybyła also wondered whether the Skinner we associate with "dusty" counting machines and pigeon cages has forever been consigned to history, or on the contrary, would he rise like a phoenix from the ashes to support the education process with a doubled strength?

Anna Czyńska then delivered a talk on the theme "Child/teenager in a democratic school". In her lecture, Ms Czyńska talked about the Droga Wolna Democratic School in Szczecin, where she is a staff member. Thanks to the talk, we could learn how the school works, that children can develop their passions there, that they are not forced to study, that they have the right to decide about themselves and their school, that they are simply happy there. The model for the functioning of the school is the profound democracy described and disseminated by Arnold Mindell.

The last speaker in this block was Jakub Adamczewski with a paper entitled "Finnish children learn better - a study of the possibilities of the Scandinavian student". $\mathrm{Mr}$ Adamczewski showed us that the Finnish education system has found a way to make education better. It made the student a partner of the teacher and not an executive agent. Mr Adamczewski could tell us all this from the perspective of a teacher who taught at a Finnish school, which was a very interesting experience. 
The speeches were followed by quite a long discussion resulting, among other things, from the great interest in Mr Adamczewski's speech.

After a short coffee break, the sixth and last part of the conference began. Wioleta Franczyk gave the first speech, presenting the topic "Comparison of the education system, school environment and student-teacher relations in Poland and Spain". The comparative analysis concerned the characteristics of education objectives, curricula and content in both countries. In her study, Ms Franczyk made a comparative analysis of the core curriculum documents and the ministerial documents of both countries. The elements connecting the two countries were also presented, which allowed us to see how education works in Spain.

Wojciech Jachnik, President of the Student History of Culture and Education Academic Club was the second speaker, presenting his paper "The way to knowledge in Taoist ideology - on the basis of the Tao Te Ching". Over the centuries, many concepts for a true path to true knowledge have emerged. The Taoist ideology proposes that we take the path through the mystical Tao. In his speech, Mr Jachnik tried to answer the question of what the Tao really is and whether we are able to define it.

Then, Sarah Taylor, also a student active in the Academic Club, gave her second talk of the day, this time on the subject of "Home schooling - from the student's perspective". The paper was based on Ms Taylor's own perspective, because for most of the years of education she herself was home schooled. Thanks to this speech, we were able to learn what opportunities a student has thanks to home schooling, what benefits it brings, the possible disadvantages - although the speaker stressed that she is personally satisfied with this system and sees mainly advantages.

At the end of the conference, Bartosz Jędrzejczak, a student of the Faculty of Educational Studies of the Adam Mickiewicz University, gave a lecture entitled "The American student. A comparison of Polish and American education". The paper was focused on the contemporary systems of American and Polish education from the student's perspective. Thanks to this analysis, the way in which education functions in both countries was presented. The aim of the paper was to identify the strengths and weaknesses of these systems. The last speech was followed by a longer discussion.

At the end of the conference, Krzysztof Ratajczak, PhD, spoke to summarise the meeting and thanked both the speakers and guests for a successful conference.

Daria Klimek

Adam Mickiewicz University in Poznań 